\title{
Uveitis associated with Lyme disease in Mexico
}

\section{Uveítis secundaria a Borreliosis de Lyme en México}

\author{
Alejandro Rodríguez-García ${ }^{1 *}$, Isidora Arroyo-Garza² and Beatriz E. Patiño-Ramirez ${ }^{2}$ \\ ${ }^{1}$ Ocular Immunology and Uveitis, Instituto de Oftalmología y Ciencias Visuales; ${ }^{2}$ Multicentric programa of Ophthalmology Residency, Tecnológico \\ de Monterrey, Escuela de Medicina y Ciencias de la Salud. Nuevo León, México
}

\begin{abstract}
Objective: Lyme disease is a rare multi-systemic infection and like in many other countries, in Mexico it is rarely considered in the differential diagnosis of certain forms of uveitis due to lack of knowledge about the risk factors of Borrelia burgdorferi infection. This report aims to review such risk factors, the clinical characteristics of ocular involvement, as well as the keys to suspect the disease in susceptible patients. Observations: A 4-year-old female with a 6-week history of bilateral red eye and blurred vision. The patient referred muscular and joints pain, skin rash, and respiratory symptoms 10 weeks before. She was previously treated for bilateral panuveitis with topical and systemic steroids during 20 days without improvement. Visual acuity was 20/200, with 3+ cells in the anterior chamber, and 2+ diffuse vitritis. Blurred right disk margins, perivascular sheathing, and multiple chorioretinal white-cream-colored infiltrates in the peripheral retina of both eyes. Multifocal chorioretinitis, papillitis, and vasculitis were diagnosed with a positive serology for B. burgdorferi. Treatment consisted in $250 \mathrm{mg}$ of oral amoxicillin every $8 \mathrm{~h}$ for 3 weeks, with complete resolution of inflammation. Conclusions: The diagnosis of Lyme disease at early stages is difficult due to its unspecific signs and inconsistent serology. Uveitis due to B. burgdorferi must be considered in every patient at risk who presents with neuro-ophthalmologic manifestations associated with chronic bilateral uveitis refractory to steroid therapy.
\end{abstract}

Key words: Ocular borreliosis. Lyme. Borrelia burgdorferi. Uveitis. Chorioretinitis. Neuroretinitis.

\section{Resumen}

Objetivo: La borreliosis de Lyme es una infección multisistémica rara, y al igual que ocurre en otros países, en México rara vez se considera en el diagnóstico diferencial de ciertas formas de uveítis debido al desconocimiento de los factores de riesgo de contagio por Borrelia burgdorferi. El presente reporte tiene como objetivo revisar dichos factores de riesgo, las características clínicas de la afección ocular, así como su sospecha en pacientes susceptibles. Observaciones: Paciente femenina, 4 años, con ojo rojo y visión borrosa bilateral de 6 semanas de evolución. Mialgias-artralgias, erupción cutánea y cuadro respiratorio las 10 semanas previas. Tratada como panuveítis bilateral con esteroides tópicos y sistémicos por 20 días sin mejoría. Agudeza visual 20/200, células 3+ en cámara anterior y vitreítis difusa 2+ en ambos ojos. Pérdida de bordes del nervio óptico derecho; exudados perivasculares e infiltrados coriorretinianos color blanco-cremoso en la periferia en ambos ojos. Se diagnosticó coriorretinitis multifocal, papilitis y vasculitis retiniana con serología positiva para B. burgdorferi. Tratada con amoxicilina $250 \mathrm{mg}$ cada $8 \mathrm{~h}$ por vía oral por 3 semanas con resolución del cuadro inflamatorio. Conclusiones: El

Correspondence:

*Alejandro Rodríguez García

Av. Batallón de S. Patricio, 112 Col. Real de S. Agustín Date of reception: 09-03-2018

C.P. 66278 , S. Pedro Garza García, N.L., México

E-mail: immuneye@gmail.com
Date of acceptance: 01-06-2018

DOI: 10.24875/RMOE.M20000093
Available online: 02-01-2020

Rev Mex Oftalmol (Eng). 2020;94(1):34-40

www.rmo.com.mx 2604-1731/C 2020 Sociedad Mexicana de Oftalmología. Published by Permanyer. This is an open access article under the CC BY-NC-ND license (http:// creativecommons.org/licenses/by-nc-nd/4.0/). 
diagnóstico de borreliosis de Lyme en etapas tempranas es difícil debido a los signos inespecíficos y la seroconversión inconstante. La uveítis por Borrelia burgdorferi debe considerarse en todo paciente bajo riesgo que presente manifestaciones neurooftalmológicas asociadas a uveítis bilateral crónica refractaria a tratamiento con esteroides.

Palabras clave: Borreliosis ocular. Lyme. Borrelia burgdorferi. Uveítis. Coriorretinits. Papilitis.

\section{Introduction}

Lyme borreliosis is a multisystemic emerging infectious disease caused by the spirochete Borrelia burgdorferi, which is transmitted by the bite from ticks of the genus Ixodes, the vector of the disease ${ }^{1}$. Ixodes scapularis, the most frequent vector in the USA and present in the state of Texas, has also been found in areas of Coahuila ${ }^{2}$. In addition, Ixodes have been identified in Baja California, the Yucatan Peninsula, the Gulf of Mexico and the northeastern area of the Mexican Republic ${ }^{3-5}$. The risk of infection is directly related to the prevalence of infected ticks and reservoirs, as well as exposure to endemic areas ${ }^{6}$.

In Mexico, the first cases of chronic migratory erythema associated with Lyme borreliosis were reported in Sinaloa and Monterrey in 19917,8. Eight years later, Gordillo, et al. reported a prevalence of $B$. burgdorferi infection of $1.1 \%$ in the general population of Mexico, meanwhile the prevalence of the white-tailed deer from the northeast of the country was of $3 \%{ }^{4}$. The deer are the final hosts of adult Ixodes, and their primary function is to preserve the vector. Another study detected Borrelia spp in $16 \%$ of the resident dogs of the Monterrey metropolitan area ${ }^{10}$. By 2003, a seroprevalence of infection by $B$. burgdorferi of $3.4 \%$ in Mexico City and $6.3 \%$ in the general population of the northeast of the country, including the states of Nuevo León, Coahuila and Tamaulipas, had been reported. Tamaulipas had the highest seroprevalence ${ }^{5}$. In 2007, the first confirmed cases of skin and neurological disease from the Valley of Mexico and Quintana Roo ${ }^{11}$ were reported.

One third of Lyme borreliosis cases occur in children under 18 years of age, and the age at greatest risk is between 5 and 14 years of age ${ }^{12}$. In Mexico, since 1999, epidemiological surveillance has been maintained to identify cases of Lyme borreliosis in childhood ${ }^{13}$. Up to 2010, seventy-two children had been studied, with a mean age of 8.5 years, of which $55 \%$ presented cutaneous manifestations, $27 \%$, neurological manifestations, and $18 \%$ arthritis. Almost $32 \%$ tested positive by immunoabsorbent enzyme assay (ELISA), and Lyme disease was confirmed in $28 \%$ of them by Western blot $^{13}$. Seventy-five percent of these children had early manifestations of the disease, which explains the low seropositivity index, while the remaining $25 \%$ showed late manifestations, but no ocular manifestations were identified in any of these cases ${ }^{13}$.

Lyme borreliosis can show several ophthalmological manifestations that are grouped into neuro-ophthalmic disorders, external ocular inflammation, intraocular inflammation, and retinal vascular disorders ${ }^{14}$. Lyme ocular borreliosis remains an underdiagnosed disease partly due to lack of awareness of its ophthalmologic manifestations and inclusion in the differential diagnosis of several ocular inflammatory disorders but also, due to the difficulty of obtaining a definitive serological diagnosis ${ }^{15,16}$. In this report, we present the first case of uveitis secondary to Lyme borreliosis described in Mexico.

\section{Case presentation}

A 4-year-old female, resident from Monclova Coahuila, who was referred to the Immunology and Uveitis Service of our institution due to red eye, extreme photophobia, and bilateral blurred vision of 6 weeks of evolution. The patient belongs to a medium-low socioeconomic class, with a relevant history of previously living in the semi-rural area of the city of Longview in northeast Texas, a geographical area considered endemic for Lyme disease by the Center for Disease Control (CDC) from Atlanta, Georgia, USA, and also in the suburban area of Monclova, Coahuila, in northeastern Mexico.

The patient had been treated for bilateral panuveitis with topical and systemic steroids for 20 days without improvement, but with deterioration of her visual and inflammatory eye status. The indirect interrogation (parents) referred myalgia and arthralgia in the lower limbs and an upper respiratory tract infection manifested with fever, general malaise, rhinorrhea, and rash for 8 days. Such symptoms started 10 weeks before consultation. On physical examination, the patient had no obvious cutaneous, neurological or rheumatic manifestations associated with Lyme disease. Initial ocular examination revealed a best-corrected visual acuity of 20/200 with myopia ( -1.25 diopters) and mild astigmatism (-0.50 diopters) in both eyes. External examination 
showed ciliary injection 1+ and biomicroscopy demonstrated fine endothelial retrokeratic precipitates with a medial-inferior distribution and $3+$ cells in the anterior chamber. The iris had no pathological alterations and the lens was clear. A diffuse vitritis of $2+$ and subtle loss of the right optic nerve borders was observed by fundoscopy (Fig. 1), as well as peripheral segmental perivascular exudates of venular predominance and multiple round chorioretinal peripheral inflammatory infiltrates of approximately $50 \mu \mathrm{m}$ in diameter, with a creamy white appearance (Fig. 2). Multifocal chorioretinitis, papillitis, and bilateral retinal vasculitis were diagnosed. In the initial approach, the following differential diagnoses were considered: juvenile idiopathic arthritis, systemic lupus erythematosus, infectious etiologies, such as syphilis, tuberculosis, atypical multifocal toxoplasmosis, bartonellosis and Lyme borreliosis. The following studies were requested: complete blood cell count, blood chemistry, C-reactive protein, erythrocyte sedimentation rate, urine analysis, antinuclear antibodies, serological determination of $\mathrm{C} 3, \mathrm{C} 4$, and $\mathrm{CH} 50$ complement fractions, tuberculin skin test (PPD), determination of fluorinated antibodies against Treponema pallidum (FTA-Abs), VDRL, IgG, and IgM antibodies against Toxoplasma gondii, Bartonella henselae, and B. burgdorferi (ELISA). The results of the serological tests were negative, except for the differential serological analysis ("2-tiered") for Lyme borreliosis, which tested positive for IgM antibodies (result: 1.21; reference: positive > 1.09) and IgG (result: 1.35; reference: positive $>1.09$ ) by ELISA, and confirmed by Western-immunoblot. The latter was positive for the p41Kd IgM (flagellin), p23Kd IgM (Osp C), and p41Kd IgG bands, specific for B. burgdorferi (LabCorp Laboratory Corporation of America, Burlington, NC. USA.; endorsed by the CDC of Atlanta, GA.)

Based on the history of living in a suburban area of Coahuila, the travel and stay in a semi-rural area in northeast Texas, the presence of an acute respiratory condition with general malaise, myalgia, arthralgia, fever, and skin rash for more than one week, in addition to the absence of response to previous topical and systemic steroids, and due to the fundus findings and serological confirmation of $B$. burgdorferi, a diagnosis of uveitis secondary to Lyme borreliosis was made. Topical treatment was started with $0.1 \%$ fluorometholone acetate every $4 \mathrm{~h}$ and amoxicillin $250 \mathrm{mg}$ every $8 \mathrm{~h}$ (weightbased dose: $50 \mathrm{mg} / \mathrm{kg} /$ day) orally for three weeks.

At the end of the treatment, absence of inflammatory cells in the anterior chamber and vitreous cavity was observed; the optic nerve borders were well-defined

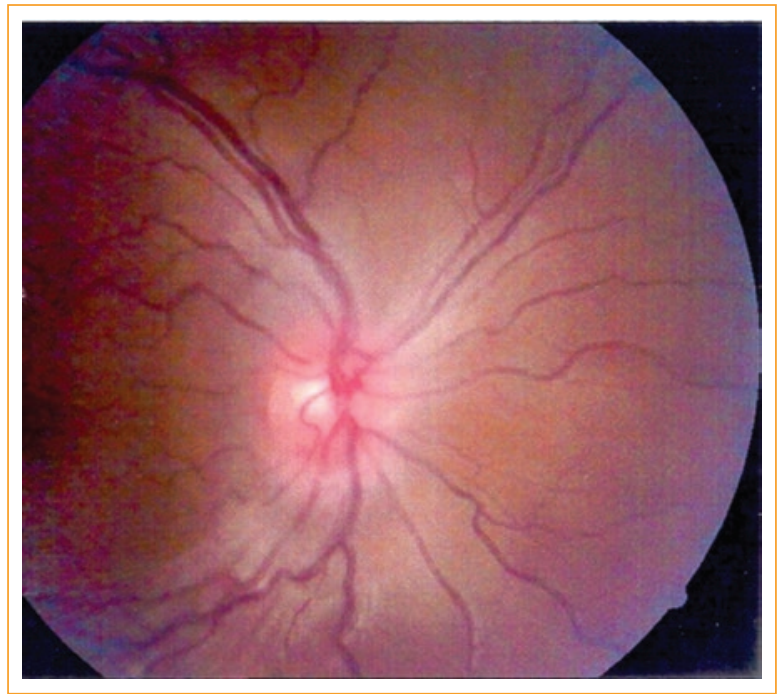

Figure 1. Right optic nerve with blurred borders, slight hyperemia and vascular congestion.

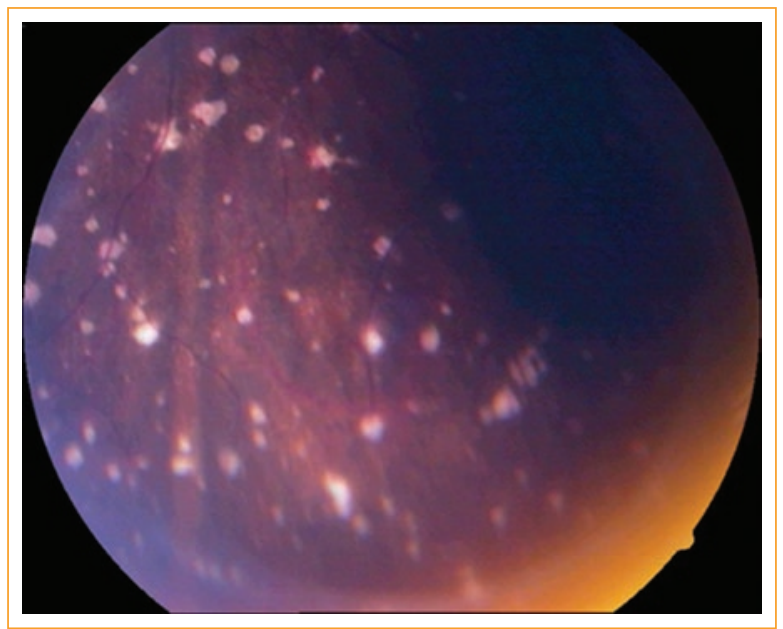

Figure 2. Multifocal white-creamy deep chorioretinal lesions, in the infero-temporal quadrant of the right eye.

(Figs. $3 \mathrm{~A}$ and $3 \mathrm{~B}$ ); there was absence of retinal vasculitis and in the peripheral retina the chorioretinal lesions were atrophic with a "punched-out" appearance (Figs. $4 \mathrm{~A}$ and $4 \mathrm{~B}$ ). Best-corrected visual acuity was $20 / 50$ in the right eye and 20/40 in the left eye. At her last follow-up visit, 4 months after treatment, the patient was asymptomatic, with no data of intraocular inflammation and with a preserved visual acuity. A new differentiated serology for Lyme borreliosis yielded negative results for antibodies by ELISA and absence of specific bands for $B$. burgdorferi by Western-immunoblot. The patient attended consultation 2 years later for 


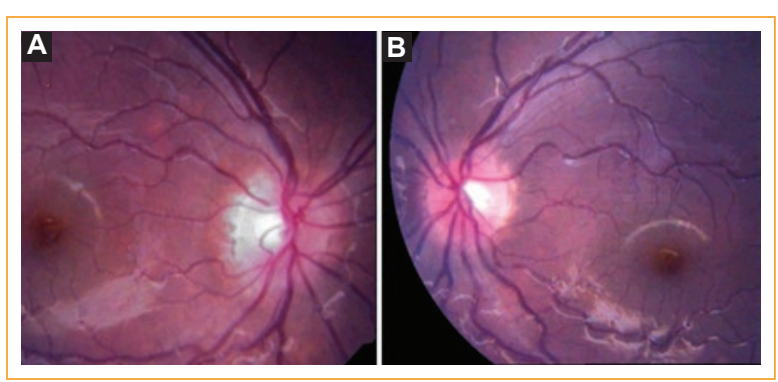

Figure 3. Right (A) and left (B) optic nerves, with well-defined borders and without vascular congestion.

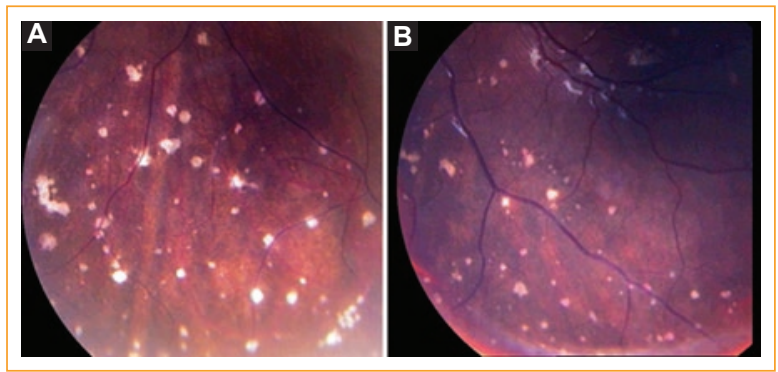

Figure 4. Peripheral retina of the right eye $(\mathbf{A})$ and left eye (B) showing multiple chorioretinal atrophic lesions with a diffuse distribution, as well as a clear vitreous.

myopia and astigmatism examination; she was asymptomatic and without any sign of active uveitis.

\section{Discussion}

Lyme borreliosis is the most common vector-borne disease in the US and some European countries ${ }^{17,18}$. Despite being up to 6 to 12 times less reported than estimated, approximately 30,000 cases are reported to the CDC every year ${ }^{18,19}$. The epidemiological context is very important for the early diagnosis of Lyme disease. Tick bites occur most likely in people who spend time in wooded habitats or with shrubs, and grasslands of endemic areas, especially between the months of May and November ${ }^{19}$. In this case, the history of having lived in an endemic area of northeastern Texas, in the US ${ }^{20}$, and of living in the northeast area of Mexico, where the greatest seroprevalence of $B$. burgdorferi infection has been reported ${ }^{5}$, as well as being the one with the highest presence of Ixodes scapularis ${ }^{2,21}$ and its natural host, the white-tailed deer $^{4}$, prompted the consideration of Lyme borreliosis in the differential diagnosis.
The clinical manifestations of Lyme disease have been divided into three stages: localized, disseminated and persistent ${ }^{1}$. The first two stages are part of the early infection with $B$. burgdorferi, while persistent disease is considered a late infection ${ }^{22}$. Table 1 shows the main multisystemic and ophthalmological manifestations, as well as the duration and diagnostic methodology used in the different stages of the disease.

It has been estimated that ocular manifestations occur in only $1 \%$ of cases and may occur in any of the three stages of the disease ${ }^{14,22}$. During the first stage, characterized by the appearance of erythema, migrans and an undifferentiated febrile condition, conjunctivitis, red eye, photophobia, and tearing can be observed ${ }^{23,24}$. Conjunctivitis is the most common manifestation, reported in up to $11 \%$ of cases and occurring almost always in the first weeks of infection ${ }^{23}$. In the second stage, dominated by neurological, and musculoskeletal symptoms, diplopia, facial palsy, internuclear ophthalmoplegia, blurred vision, and eye pain can be observed, as well as keratitis, episcleritis, anterior uveitis, multifocal chorioretinitis, papillitis, panophthalmitis, retinal venous obstructions, exudative retinal detachment, and orbital myositis ${ }^{14,24,25}$. In the third stage, characterized by rheumatologic (arthritis), and neurological symptoms, all the ocular manifestations described in the second stage usually occur, but especially the most severe, such as intraocular inflammation ${ }^{12,16,24,26}$. Intermediate uveitis is the most common form, but multifocal chorioretinitis is also observed as in this case, with retinal vasculitis ${ }^{14}$. It has not been established whether late-stage patients represent a failure to antibiotic treatment, or persistence of Borrelia, a new infection with another tick-borne pathogen or perhaps an autoimmune phenomenon ${ }^{26}$.

In this report, everything suggests that the patient was in the second stage due to the time elapsed from the respiratory and unspecific febrile symptoms until the onset of ocular symptoms. Apart from the positive serological results and the type of ocular manifestations like multifocal chorioretinitis, retinal vasculitis, and papillitis, which are clinical manifestations consistent with this stage, the patient did not show rheumatic or neurological symptoms.

Erythema migrans is the clinical indicator of Lyme borreliosis; however, in $20 \%$ of cases, no rash is observed $^{27}$. In endemic areas, patients with erythema migrans and recent exposure to tick bites do not require serological studies for diagnosis ${ }^{19,27}$. In these early stages of the disease, the possibility of false negative serological results is high and when these tests are positive, they fail to distinguish between an active or 
Rev Mex Oftalmol (Eng). 2020;94

Table 1. Systemic and ocular clinical features at different stages of Lyme borreliosis

\begin{tabular}{|c|c|c|c|}
\hline Stage & Multisystemic manifestations & $\begin{array}{l}\text { Ophthalmological } \\
\text { manifestations }\end{array}$ & $\begin{array}{l}\text { Time of onset and diagnostic } \\
\text { method }\end{array}$ \\
\hline $\begin{array}{l}\text { First: Early } \\
\text { localized }\end{array}$ & $\begin{array}{l}\text { Erythema migrans ( } 66 \% \text { of cases), starts } 7 \text { days } \\
\text { post-bite and persists for } 2-3 \text { weeks. } \\
\text { Undifferentiated febrile illness ( } 50 \% \text { of cases), } \\
\text { starts } 1-7 \text { days post-bite. Fever, chills, malaise, } \\
\text { fatigue, myalgia, arthralgia, and headache. }\end{array}$ & $\begin{array}{l}\text { Conjunctivitis, red eye, } \\
\text { photophobia, and tearing. }\end{array}$ & $\begin{array}{l}\text { Begins 1-30 days post } \\
\text { infection. } \\
\text { Clinical diagnosis. Serological } \\
\text { tests are not } \\
\text { recommended (due to false } \\
\text { negatives). }\end{array}$ \\
\hline $\begin{array}{l}\text { Second: Early } \\
\text { disseminated }\end{array}$ & $\begin{array}{l}\text { Neurological ( } 5-20 \% \text { of cases), facial palsy, } \\
\text { more common, meningitis and } \\
\text { radiculopathy (Lyme triad), as well as } \\
\text { encephalopathy, and } \\
\text { musculoskeletal: migratory polyarthritis that } \\
\text { evolves into a monoarticular process (knee, } \\
\text { ankle, and wrist). }\end{array}$ & $\begin{array}{l}\text { Diplopia, internuclear } \\
\text { ophthalmoplegia, facial palsy, } \\
\text { papilledema, blurred vision, } \\
\text { pain, keratitis, episcleritis, and } \\
\text { scleritis, uveitis (multifocal } \\
\text { chorioretinitis), papillitis, } \\
\text { panophthalmitis. }\end{array}$ & $\begin{array}{l}\text { Arthritis starts from 3-10 weeks } \\
\text { and meningitis from } \\
2-10 \text { weeks post infection. } \\
\text { IgM and IgG antibodies } \\
\text { against } B \text {. Burgdorferi (ELISA), } \\
\text { confirmed by Western blot. } \\
\text { PCR (limited availability) }\end{array}$ \\
\hline $\begin{array}{l}\text { Third: Late } \\
\text { persistent or } \\
\text { chronic }\end{array}$ & $\begin{array}{l}\text { Rheumatic: knee arthritis ( } 90 \% \text { cases), and } \\
\text { neurological: subacute encephalopathy, } \\
\text { progressive chronic encephalomyelitis, axonal } \\
\text { neuropathy, and myelitis ( } 50 \% \text { cases). } \\
\text { Acrodermatitis chronica atrophicans on the } \\
\text { back of the hands, feet, knees, and } \\
\text { elbows (European). }\end{array}$ & $\begin{array}{l}\text { Anterior, intermediate, or } \\
\text { posterior uveitis, panuveitis, } \\
\text { retinal vasculitis, orbital } \\
\text { myositis, exudative retinal } \\
\text { detachment, central, and } \\
\text { branch vein occlusions. }\end{array}$ & $\begin{array}{l}\text { Begins months to years after } \\
\text { initial infection. IgG antibodies } \\
\text { against } B \text {. Burgdorferi (ELISA), } \\
\text { confirmed by Western blot. } \\
\text { PCR (limited availability) }\end{array}$ \\
\hline
\end{tabular}

ELISA: immuno-absorbent enzyme assay; PCR: polymerase chain reaction.

past infection ${ }^{28}$. In the same regard, the sensitivity of the differentiated serological analysis ("2-tiered") to detect IgM and IgG antibodies against $B$. burgdorferi in the serum of patients when the humoral immune response is developing, is of only $30-40 \%{ }^{28,29}$. Therefore, the diagnosis of Lyme ocular borreliosis in early stages of the disease is difficult, since it is based on nonspecific clinical findings related to ocular surface inflammation, intraocular inflammation or neuro-ophthalmic alterations in patients with a high risk of infection ${ }^{30}$. For disseminated Lyme disease, the sensitivity of serological tests increases to $70-100 \%$, while the specificity is high $(95 \%)$ during all stages of the disease ${ }^{15}$. Other diagnostic tests are direct tests, specifically culture and polymerase chain reaction (PCR). Culture is not available for routine use; it is technically difficult to perform and is characterized by low diagnostic sensitivity. On the other hand, PCR is only performed in the synovial fluid of patients with arthritis and a suspected diagnosis of the disease, and there are isolated reports of its diagnostic utility in ocular tissues, such as conjunctiva, aqueous or vitreous humor ${ }^{31,32}$. Thus, the diagnosis of uveitis secondary to Lyme borreliosis is based on the history of exposure to tick bites or hazardous environments; on a positive differential serological analysis during the disseminated and persistent stages; on the resistance to steroid treatment, and on the favorable response to antibiotic therapy, as well as on the exclusion of other potential diagnoses ${ }^{33,34}$. In this case, the patient had an epidemiological history considered as a risk for developing Lyme borreliosis, did not show improvement with steroid treatment and the serology for other causes of uveitis was negative. In addition, she had a frankly positive and confirmatory result of infection with $B$. burgdorferi by differentiated serology. In this regard, the patient was positive for p23Kd and $\mathrm{p} 41 \mathrm{Kd}$ IgM bands and $\mathrm{p} 41 \mathrm{Kd} \lg \mathrm{g}$ bands against $B$. burgdorferi by protein electrophoresis, which are typical in Lyme disease and that became negative after the fourth month of treatment ${ }^{27,29}$. During the clinical course of Lyme borreliosis, seroconversion by ELISA and Western blot is observed, changing from positive to negative and vice versa, without following a regular pattern ${ }^{35}$.

The differential diagnosis of Lyme ocular borreliosis should include any of the potential causes of the neuro-ophthalmic and inflammatory ocular manifestations observed in these cases, including viral conjunctivitis, herpes simplex virus, and varicella zoster infections, Rocky Mountain fever, Horner syndrome, sarcoidosis, facial, and trochlear paralysis, optic neuritis, sarcoidosis, syphilis, among others $22,24,36$.

In terms of management, the conjunctivitis observed at the first stage of the disease usually does not require treatment, as is the case for the facial palsy observed in the second stage, which is usually self-limited, but 
complications from exposure keratitis require supportive therapy. Episcleritis and keratitis are usually treated with a short course of topical steroids ${ }^{25}$. On the other hand, in the case of neuro-ophthalmic disease with optic nerve involvement or intermediate uveitis, posterior uveitis, and panuveitis, the use of systemic steroids should be accompanied by antibiotic therapy. Usually the treatment consists of 2 to 3 weeks of penicillin-G, doxycycline, cefuroxime, cefotaxime, or ceftriaxone ${ }^{26}$. In childhood, the first-choice oral antibiotic is amoxicillin ( $50 \mathrm{mg} / \mathrm{kg} / \mathrm{day}$ up to a maximum dose of $500 \mathrm{mg} /$ day), which is why in this case we decided to use it, although penicillin $\mathrm{V}$ sodium, and ceftriaxone may also be used ${ }^{37}$. A systematic review of antibiotic therapy in children with Lyme borreliosis found no difference in therapeutic efficacy between different antibiotics ${ }^{37}$. Recurrences of Lyme borreliosis, especially third-stage arthritis, are treated with steroids ${ }^{26}$.

Our patient was a 4-year-old in the second stage of the disease, and had received systemic steroids for 3 weeks without response. For these reasons it was decided to suspend them. In conclusion, uveitis secondary to Lyme borreliosis is a rare entity probably underdiagnosed in our country. The limited epidemiological information and the lack of serological scrutiny in patients with suspected disease, contribute to the low diagnosis. When any bilateral panuveitis is under study, an exhaustive interrogation must be performed, including history about the way and place of living (geographical area), especially of high-risk habitats for $B$. burgdorferi infection. In our country, such history should be considered, especially in patients from the northeast area and its border with the state of Texas, USA. In any suspected or at-risk patient with neuro-ophthalmic manifestations associated with bilateral uveitis and in whom other infectious and frequent immune processes that do not respond to steroids have been ruled out, Lyme borreliosis should be considered as a differential diagnosis.

\section{Ethical disclosures}

Protection of human and animal subjects. The authors declare that no experiments were performed on humans or animals for this study.

Confidentiality of data. The authors declare that they have followed the protocols of their work center on the publication of patient data.

Right to privacy and informed consent. The authors declare that no patient data appear in this article.

\section{Conflicts of interest}

None to report.

\section{References}

1. Pfister HW, Wilske B, Weber K. Lyme borreliosis: basic science and clinical aspects. Lancet. 1994;343:1013-6.

2. Keirans JE, Hutcheson HJ, Durden LA, Klompen JSH. Ixodes (Ixodes) scapularis (Acari: Ixodidae): redescription of all active stages, distribution, hosts, geographical variation, and medical and veterinary importance. J Med Entom. 1996:33:297-318.

3. Kohls GM, Clifford CM. Three new species of Ixodes from Mexico and description of the male of I. auritulus auritulus Neumann, I. conepati Cooley and Kohls, and I. lasallei Mendez and Ortiz (Acarina: Ixodidae). J Parasitol. 1966;52:810-20.

4. Martinez A, Salinas A, Martinez F, Cantu A, Miller DK. Serosurvey for selected disease agents in white-tailed deer from Mexico. J Wild Life Dis. 1999:35:799-803.

5. Gordillo-Pérez G, Torres J, Solórzano-Santos F, Garduño-Bautista V, Tapia-Conyer R, Muñoz HO. Estudio seroepidemiológico de borreliosis de Lyme en la ciudad de México y el noreste de la república mexicana. Salud Publica Mexico. 2003:45:351-5

6. Steere AC, Malawista SE. Cases of Lyme disease in the United States: Locations correlated with distribution of Ixodes dammini. Ann Intern Med. 1979:91:730-3.

7. Vargas MH. Lyme disease in Mexico City. Salud Publica Mexico. 1993;35:435-6.

8. Arroyave CM, González RT. Enfermedad de Lyme: Informe de dos casos. Bol Med Hosp Infant Mex. 1994:51:117-21.

9. Gordillo-Pérez G, Solórzano-Santos F, Torres L, Cedillo RR, Tapia CR, Muñoz HO. Serological evidence of Lyme disease in Mexico. Arch Med Res. 1999:30:64-8.

10. Salinas-Meléndez JA, Avalos-Ramírez R, Riojas-Valdez VM, Martínez-Muñoz A. Serological survey of canine borreliosis. Rev Latinoam Microbiol. 1999:41:1-3.

11. Gordillo-Pérez G, Torres J, Solórzano-Santos F, de Martino S, Lipsker D, Velazquez E, et al. Borrelia burgdorferi infection and cutaneous Lyme disease, Mexico. Emerg Infect Dis. 2007;13:1556-8.

12. Huppertz HI, Münchmeier D, Lieb W. Ocular manifestations in children and adolescents with Lyme arthritis. Br J Ophthalmol. 1999;83:1149-52.

13. Gordillo-Pérez MG, Solórzano-Santos F. Enfermedad de Lyme. Experiencia en niños mexicanos. Bol Med Hosp Infant Mexico. 2010;67:164-76.

14. Mikkilä HO, Seppälä IJ, Viljanen MK, Peltomaa MP, Karma A. The expanding clinical spectrum of ocular lyme borreliosis. Ophthalmology. 2000:107:581-7.

15. Moore A, Nelson C, Molins C, Mead P, Schriefer M. Current guidelines, common clinical pitfalls, and future directions for laboratory diagnosis of Lyme disease, United States. Emerging Infect Dis. 2016;22:1-9.

16. Rodriguez-Garcia A, Vidaurri-Leal JS. Ocular manifestations of systemic granulomatous diseases. Current Opinion Ophthalmol. 1991;2:181-89.

17. van den Wijngaard CC, Hofhuis A, Simões M, Rood E, van Pelt W, Zeller H, et al. Surveillance perspective on Lyme borreliosis across the European Union and european econonomic area. Eurosurveillance.com 2017:22:1-9.

18. Centers for Disease Control and Prevention. Lyme disease data. CDC. Disponible en: http://www.cdc.gov/lyme/stats/index.html?s_cid=cs_281. September 24, 2015; Último acceso: 14 agosto, 2017.

19. Mead PS. Epidemiology of Lyme disease. Infect Dis Clin North America. 2015;29:187-210.

20. Dandashi JA, Nizamutdinov D. Texas occurrence of Lyme disease and its neurological manifestations. J Neuroinfect Dis. 2016;7:1-5.

21. Skinner-Taylor CM, Flores-González MDS, Valerio E, Antonio J, Salinas-Meléndez JA, Salinas-Palacios, et al. Evidencia de la enfermedad de Lyme en una población de alto riesgo del noreste de México. Medicina Universitaria. 2007;9:105-11.

22. Karma A, Seppälä I, Mikkilä H, Kaakkola S, Viljanen M, Tarkkanen A. Diagnosis and clinical characteristics of ocular Lyme borreliosis. Am J Ophthalmol. 2014;119:127-135.

23. Mombaerts I, Maudgal PC, Knockaert D. Bilateral follicular conjunctivitis as a manifestation of Lyme disease. Am J Ophthalmol. 1991;112:96-7.

24. Raja H, Starr MR, Bakri SJ. Ocular manifestations of tick-borne diseases. Surv Ophthalmol. 2016;61:726-44.

25. Flach AJ, Lavoie PE. Episcleritis, conjunctivitis, and keratitis as ocular manifestations of Lyme disease. Ophthalmology. 1990;97:973-5.

26. Meyerhoff JO, Steele RW, Zaidman GW. Lyme Disease. Update June 29, 2017. In emedicine.medscape.com/article/330178. Último acceso: 2 septiembre, 2017.

27. Centers for Disease Control and Prevention (CDC) Recommendations for test performance and interpretation from the Second National Conference on Serologic Diagnosis of Lyme Disease. MMWR. 1995;44:590-1. 
Rev Mex Oftalmol (Eng). 2020;94

28. Marques AR. Laboratory diagnosis of Lyme disease: Advances and challenges. Infect Dis Clin North America. 2015;29:295-307.

29. Branda JA, Strle K, Nigrovic LE, Lantos PM, Lepore TJ, Damle NS, et al. Evaluation of modified 2-tiered serodiagnostic testing algorithms for early Lyme disease. Clin Infect Dis. 2017;64:1074-80.

30. Kazi H, de Groot-Mijnes JDF, Dam-van Loon ten NH, Norel JO-V, Oosterheert $\mathrm{JJ}$, de Boer $\mathrm{JH}$. No value for routine serologic screening fo Borrelia burgdorferi in patients with uveitis in the Netherlands. Am J Ophthalmol. 2016;166:189-93.

31. Marques AR. Laboratory diagnosis of Lyme disease - Advances and challenges. Infect Dis Clin North Am. 2015;29:295-307.

32. Mikkilä H, Karma A, Viljanen M, Seppälä I. The laboratory diagnosis of ocular Lyme borreliosis. Graefe's Arch Clin Exp Ophthalmol. 1999; 237:225-30
33. Bernard A, Kodjikian L, Abukhashabh A, Roure-Sobas Ch, Boibieux A Denis P, et al. Diagnosis of Lyme-associated uveitis: value of serological testing in a tertiary centre. Br J Ophthalmol Published Online First: 28 June 2017.

34. Qureshi IA, Maldonado MF, Rodriguez GJ, Cruz-Flores S, Maud A. Optic neuritis in acute neuroborreliosis (Lyme disease) in the U.S.-Mexican border: Case report. World J Neuroscience. 2016;6:126-30.

35. Aberer $\mathrm{E}$, Schwantzer G. Course of antibody response in Lyme borreliosis patients before and after therapy. ISRN Immunology 2012; 2012, Article ID 719821, 4 pages.

36. Lesser RL, Kornmehl EW, Pachner AR, Kattah J, Hedges TR, Newman NM, et al. Neuro-ophthalmologic manifestations of Lyme disease. Ophthalmology. 1990;97:699-706.

37. Dersch R, Hottenrott T, Schmidt S, Sommer H, Huppertz HI, Rauer S, et al. Efficacy and safety of pharmacological treatments for Lyme neuroborreliosis in children: a systematic review. BMC Neurology. 2016;16:189 